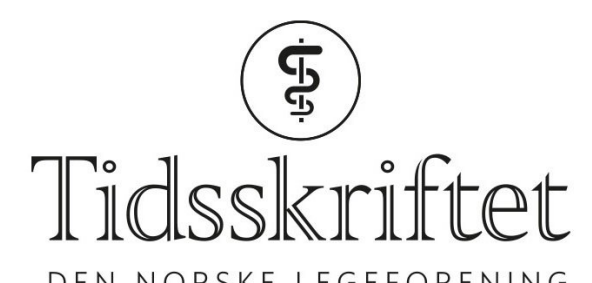

DEN NORSKE LEGEFORENING

\title{
P. Gjersvik svarer
}

KOMMENTAR

\section{PETTER GJERSVIK}

E-post: petter.gjersvik@medisin.uio.no

Petter Gjersvik er professor ved Institutt for klinisk medisin, Universitetet i Oslo. Forfatteren oppgir ingen interessekonflikter.

Jeg takker for gode kommentarer fra Arild Bjørndal, som mener det engelske uttrykket evidence-based medicine bør oversettes til kunnskapsbasert praksis på norsk.

Det er vanskelig å være uenig i at medisinsk praksis skal være basert på kunnskap. I mine $\emptyset$ rer blir dermed uttrykket kunnskapsbasert praksis lite meningsbærende og altfor upresist. Søk på Nasjonalbibliotekets database med søkeord 'kunnskapsbasert praksis' vil også omfatte andre fag enn medisin.

Gode oversettelser er gjerne kjennetegnet av at de er lette å oversette tilbake til det opprinnelige ordet. Kunnskap og praksis på norsk må oversettes til henholdsvis knowledge og practice på engelsk. Det er nå en gang slik at det heter evidence-based medicine på engelsk, ikke knowledge-based practice. Når man ikke er helt fornøyd med et engelsk uttrykk, er det fristende, men ikke å anbefale, å prøve å forbedre det. Hvis man likevel velger å gjøre det, er det ikke lenger en oversettelse, men et fors $\emptyset \mathrm{k}$ på å etablere et nytt begrep.

Publisert: 9. desember 2019. Tidsskr Nor Legeforen. DOI: 10.4045/tidsskr.19.0743

(C) Tidsskrift for Den norske legeforening 2020. Lastet ned fra tidsskriftet.no 